\title{
The Male Child Syndrome in Chimamanda Ngozi Adichie's Fiction
}

\author{
Prof. Laure Clémence Capo-Chichi Zanou ${ }^{1 *}$, Dr Célestin Gbaguidi ${ }^{2}$, Hubert kpavodé ${ }^{3}$ \\ Université d'Abomey-Calavi, Benin \\ *Corresponding Author: Prof. Laure Clémence Capo-Chichi Zanou, Université d'Abomey-Calavi, \\ Benin

\begin{abstract}
In African societies, the birth of a baby boy is an occasion of great rejoicing. Many people prefer to have a baby boy than have a baby girl. My objective in undertaking such a research work is to investigate the reasons why people long for male children and not for female ones and the consequences it has on their lives. The feminist literary theory is applied to carry out the work. I have discovered that guaranteeing one's place, immortalising one's bloodline and inheritance laws lead people to look for baby boys.
\end{abstract}

Keywords: Rejoicing, Male Child, Immortalising, Inheritance.

\section{INTRODUCTION}

In many African societies, one of the criteria to measure a woman's worth is her ability to bear children. The society expects from any married woman offspring. Because "a childless marriage is not a family" (Ayisi, 1980, p.15). If a woman fails in fulfilling that societal demand, she is ridiculed, abused, stigmatised, victimized and endures all sorts of humiliation. African societies are too demanding vis -à- vis the woman when it comes to motherhood and child bearing. And one thing is to bear children but another thing is to succeed in bearing male children. This belief perpetuated over generations is sustained by patriarchy, a system which promotes the domination of men and boys over women and girls.

A. H. El-Gilany \&E. Shady(2007)quoted by Ine Nnadi ${ }^{1}$ observed that the preference for sons by culture and custom is a widely known phenomenon in several developing nations where the status of women is low and subordinate to their male counterparts.

Furthermore Navtej K. Purewal(2012) quoted in Ine Nnadi declared that "the preference for male children transcends many societies and cultures, making it an issue of local and global dimensions. While son preference is not a new phenomenon and has existed historically in many parts of Asia, its contemporary expressions illustrate the gender outcomes of social power relations as they interact and intersect with culture, economy and technologies"(p135). The two quotations above show that son preference is not peculiar to one region but can be observed worldwide. Nigeria and particularly the Igbo society is no exception in this regards. Male child preference is a striking feature of that ethnic group.

As a result, fictional works whether authored by men or women display the phenomenon. In this dynamic Chimamanda Ngozi Adichie, one of the Nigerian women writer exposed the fact from a woman's angle in her novels and collection of short stories. This paper sets out to investigate the reasons why people long excessively for male children in Adichie's works, the consequences this attitude has on them and Adichie's solutions to curb the phenomenon as it is a form of violence against women. This topic has been tackled from a feminist standpoint.

To carry out the work, I proceed from an analytical and descriptive method with focus on Adichie's first two novels namely Purple Hibiscus and Half of a Yellow Sun are the raw materials used to reach my goal.

\footnotetext{
${ }^{1}$ Ine Nnadi Son preference-A Violation of Women's Human Rights; A case study of Igbo custom in Nigeria; journal of Politics and Law, vol6. N1; 2013; published by Canadian Center of Science and Education
} 


\subsection{The reasons why people prefer male children to female ones}

\subsubsection{Guaranteeing One's Place in the Household}

Ezeigbo comments that traditionally the narratives by Igbo women deal with their own tales and experiences "because that is the one experience they can handle with a marked degree of competence, having been nurtured in that culture which gave rise to the experience" (Akachi, p. 155). This is illustrated in the works of Nigerian Igbo women writers such as Flora Nwapa, Buchi Emecheta, Unoma Azuah, Ifeoma Okoye, to name but a few. They discussed themes such as polygamy, rape, gender-based violence, motherhood, female empowerment, patriarchy etc. Chimamanda Ngozi Adichie is no exception in this regard. She portrays vividly and realistically the problems African women in general and Igbo women in particular are confronted with in their day to day life. Among these themes, we have the male child preference.

The theme of male child syndrome permeates all Adichie's texts. Purple Hibiscus (henceforth will be $\mathrm{PH})$ is Adichie's first novel. "Eugene rules his household with a rigid hand: he likes order and everything in the house has a schedule and must be followed as such. Failure to do so attracts reprimands and serious beatings. This makes his wife, Beatrice, and children, Kambili and Jaja live in perpetual fear of him" (Ikediugwu, 2013, p.11). The main character Eugene Achike always abuses his wife and children and this leads the woman to have many miscarriages. This prevents her from having many children especially sons. She ends up having one boy and one girl and this situation worries her. In spite of all the harsh treatments meted out to Beatrice, she doesn't divorce divorce her husband and is thankful to him. "Beatrice honestly plays her social responsibilities well even though she is brutally abused by her husband. She remains in the marriage for the sake of her children. She serves her husband and children dutifully as a wife and a mother." (Sam et al., 2017, P.799). "To her, marriage is very important for every woman and no matter what happens; a woman must stick to her marriage and do well to keep it intact (Denkyi-Manieson, 2017, p. 53). One of the reasons is that she has only one son and could have been threatened in her marriage. The novel is set in Igboland in Nigeria, an African region where people are used to having many children. In African traditions, the number of children, especially the male ones, in a family determines the capacity to continue the lifeblood. Beatrice is married to a famously wealthy businessman. This is an additional reason for her to worry to get more wives. She fearfully told her daughter:

"The members of our Umunna even sent people to your father to urge him to have children with someone else. So many people had willing daughters and many of them were university graduates too. They might have borne many sons and driven us out, like Mr Ezendu's second wife did".2. (Adichie, 2003, p.20)

The excerpt shows that a first wife can be driven out by the second wife who is more fertile. Beatrice is aware of that and she is fearing for her inability to bear many children as she has only one girl one son. She knows that the fact of having only one son is a threat to her. It can be one day the reason for her being driven out. It is then clear that male children are pillars on which an African woman stands in a household. Failure to have them means that one day she may be driven out without anything. In this regard, Fwangyil opinions that:

"The phallocentric notion that a woman must have many male sons in order to be valued culturally makes Beatrice to feel insecure. The villagers believe that a man with Eugene's wealth and position in the society should not have just two children. This belief contributes to Beatrice's trauma after the second miscarriage "3. (p. 268)

Fwangyil's statement confirms the fact that wealthy people in Igbo context are not expected to have just two children. Eugene is expected to have many wives and many children. When they are many women in a man's house they harm one another out of jealousy. Beatrice, Eugene's wife in PH fears being driven out. And when a wife is driven out of a house she loses everything. African culture value male children and the woman who bore them. As a result a woman who fails to have them feel

\footnotetext{
${ }^{2}$ Chimamanda Ngozi Adichie, Purple Hibiscus, $\mathrm{p}(20)$

${ }^{3}$ Fwangyil, A. Gloria." A Reformist-Feminist Approach to Chimamanda Ngozi Adichie's Purple Hibiscus" in African Research Review, 5, May 2011, p(268)
}

International Journal on Studies in English Language and Literature (IJSELL) 
insecure. So a male child represents a guarantee for his mother; her age-old security. The value of a woman is measured in accordance to her ability to bear many sons. It is a woman's prestige. It is an insurance that she will stay with her husband till the end of her days. Male children are the pillars on which their mother stand. This is what Chimamanda Ngozi Adichie tries to illustrate through her mouthpiece Anulika in Half of a Yellow Sun. (Henceforth will be HYS)

Anulika is the younger sister of Ugwu, the houseboy brought to Nsukka to stay with Odenigbo. Right after being married, she is expressing the desire to have a baby boy first. She avows: "I want a baby boy first because it will place my feet firmly in Onyeka's house" (Adichie, 2006, p. 119). As young as she is, Anulika has already known the importance or value of a male child in a woman's life. She knows that failure to have it may cause her ejection or ill-treatment in Onyeka's house. The quote also means that a woman who does not have a baby boy first is in an unbalanced position. She will not be well-treated by her husband. She will not get any favour from him either. In other words, the treatment a woman receives from her husband partly depends on the sex of the child she will give him. Anulika's statement confirms Beatrice's fear and insecurity. A male child is a guarantee that a woman will not be sent out from her household. He represents a rock for his mother. In furtherance of the same idea, Anulika recalls the story of a woman who fails to give birth to a baby boy first:

\section{"You know Onunna from Ezeugwu's compound had a baby girl first and her husband's people went to see a dibia to find out why! Of course, Onyeka's people will not do that to me, they don't dare but I want to have a boy first anyway". (Adichie, 2006, p. 119)}

The statement is an indication of how people value male children in Igbo community and by extension Nigeria. To have a girl first is considered an abnormality and they need to find out why. People have ingrained in their mind the fact that a boy should be the first offspring that must come in a couple. The absence of the habitual boy first take them to the dibia's house. In Africa and especially in Nigeria, a dibia is consulted when something unexpected happens, when misfortune befalls people or when people want to find out about the future. So the birth of the baby girl first is an unexpected event or a misfortune; the reason of which should be found out. Anulika also acknowledges that Onyeka's parents will not do that to her. This means that the fact of going to the dibia is a wrong they are doing to the woman. A child is a gift from God and nobody is responsible for a baby's sex, only God makes it.

\subsection{Male Children as Heirs}

Most women in patriarchal societies depend on their husband financially. So after the death of the husband, they become miserable and because they are dispossessed of everything and become vulnerable if there is no son to inherit and continues the management of his father's properties. Therefore, children can be seen as old age security to their parents and sons are their mother's hope and security after the father's death. The preciousness of a male child is further underscored when a woman member of the Achike's family declares during a visit to their homeland Abba that:

\section{"Nekene, see the boy that will inherit his father's riches!...If we did not have the same blood in our veins, I would sell you my daughter"5. (Adichie, 2003, p.91)}

This statement justifies Beatrice's fear and at the same time represents a comfort for her. It means that it is a boy who can inherit his father's properties and if she doesn't have Jaja as son, the riches of her husband would go to people outside the household after his death. The excerpt also confirms that a female child can in no way inherit her father's properties after the death of the latter. This is a common practice in many African rural areas where women do not have right to property. Beatrice will therefore owe her sanity, her safety and well- being to her son Jaja who is incontestably the heir of his father. Eugene owns many businesses and is one of the most famous citizens of Enugu. He also helps many people financially. For this reason; he is called the Omelora, the one who does for the community. He is also the only son of his parents. In the African context an only son is expected to have many wives and male children in order to enlarge or broaden his lineage. In Enugu and even throughout the country, Eugene's newspaper The Standard, known for its outspokenness makes him more popular. All this represents a pride and privilege to Beatrice because she has no job outside her

\footnotetext{
${ }^{4}$ Chimamanda Ngozi Adichie, Half of a Yellow Sun, p(119)

${ }^{5}$ Chimamanda Ngozi Adichie, Purple Hibiscus, p(91)
} 
home apart from caring for her children and husband. Her workplace is the kitchen. So life without Eugene will not be easy for her if there is no son around. The second part of the statement showcases how women are underrated and underestimated to the extent of being considered an object of sale. By saying "I would sell my daughter to you" (Adichie, 2003, p.91). The woman means she would get a great amount of money, kola nuts or palm wine according to her custom from Jaja. We can also guess from the statement that the two human beings (boy and girl) do not have the same value or importance. There is one that can be sold and another that everyone longs for and that must rightfully inherit riches after the departure of his parents. For that village woman, a female child is not as valuable as a male one and a girl is somebody that one can sell out to another family.

No wonder Chief Ozobia in Half of a Yellow Sun wants to exchange his more beautiful daughter Olanna for a business contract. The excerpt shows that people have a low image of women whereas men are highly valued in a patriarchal society like Nigeria. "In the male dominated society, women have fewer legal rights... (Sam, Georshia, \& Remya, 2017, p. 796). Adichie through her writing is denouncing such negative ideas or stereotypes people have of women. All human beings are created equal and nobody should be considered a commodity that can be sold.

\subsection{The Immortalisation of the Bloodline or Lineage}

Another reason why people prefer male children over female ones is the immortalisation of the bloodline. In Chimamanda Ngozi Adichie's Purple Hibiscus Eugene Achike, the main character has been to missionary school and now he is ill-treating his own father Papa Nnukwu. He allows his two children to see him for only fifteen minutes in a whole year. He rejects him and refuses to assist him financially because he has refused to join him worship the white man's God. And the old man is blaming the missionaries for this situation. Aunty Ifeoma thinks that the fact of having been to the missionary school should not be an excuse because she too has been to the same school. To her great amazement, Papa Nnukwu replies to her: "but you are a woman, you do not count", (Adichie, 2003, p. 83). Papa Nnukwu can be seen as a pure product of patriarchy. He has said openly what many people in patriarchal societies think and believe in the bottom of their heart. In spite of all Aunty Ifeoma's achievements, Papa Nnukwu thinks she does not count because she is a woman. A woman does not count in a patriarchal society, patriarchy recognizes only the power and achievement of men and fathers. Papa Nnukwu's reaction can also be understood by the fact that a male child immortalises his bloodline whereas a female child immortalises her husband's bloodline. Papa Nnukwu knows that he owes his survival to Aunty Ifeoma but none of her children can bear his name and in Africa everybody wants their lineage to be as large as possible. Before coming to her daughter's house in Nsukka, he lived for many years in his village Abba and is aware of the importance people place on male children.

The immortalisation of the bloodline is also underscored in Adichie's second novel Half of a Yellow Sun, where she portrays characters valuing male children more than they do to female ones. Mama Odenigbo wants somebody that will carry on her family name; that is why when Amala was pregnant and she was not feeling well she declares: "My enemies want to harm the pregnancy, they do not want somebody to carry on our family name, but we will defeat them "8 (Adichie, 2003,p. 239). Once again we have another indication of the reason why people long for male children. They want somebody who will carry on their family name and immortalise it. It is risky to have only girls because girls may not carry their father's name after marriage and their children bear another man's name, their father. Therefore, the continuation of the lineage is threatened. Mama Odenigbo is not preoccupied with whether her son loves Amala or not. She is from rural area and in rural areas, boys are highly valued.

The importance of the male child in enlarging the lineage is also discussed in Adichie's collection of short stories The Thing Around Your Neck (henceforth will be TAYN). In this collection of short stories, the story "Tomorrow is too far" portrays a grandmother who discriminates openly against her granddaughter while her grandson is well cherished. The grandson's name is Nonso and has the care of his Grandmother who always says to him: "Eat a little more, [...] Who do you think I made it for?",

\footnotetext{
${ }^{66}$ Chimamanda Ngozi Adichie, Purple Hibiscus, p(91)

${ }^{7}$ Chimamanda Adichie, Purple Hibiscus, Farafina, p(83)

${ }^{8}$ Chimamanda Adichie, Purple Hibiscus, Farafina, p(239)

${ }^{9}$ Chimamanda Ngozi Adichie, The Thing Around Your Neck, p(195)
} 
(Adichie, 2009, p. 195). This is an example of Grandmother's care and nurture for Nonso while his sister is ignored. The Grandmother as a woman kneaded with experience knows the culture of her society and what will happen in the future; only the boy will stay in his father's house but the girl will be married off for the bliss of another family. On this basis, Nonso receives a lot of attention and care. $\mathrm{He}$ is begged to eat even if he is satisfied. He gets from Grandmother the attention all the children together should have. She taught Nonso how to pluck the coconuts ${ }^{10}$ (Adichie, 2009, p. 187) and refuses to teach girls. To make children drink coconut milk, she makes sure Nonso drinks first though her sister is older than he is. When asked why she behaves in such a way she declares that Nonso was her son's son, the one who would carry on the Nnabuisi name while Dozie was only a nwadiana her daughter's son ${ }^{11}$ (Adichie, 2009, p. 188). So it is Nonso who would immortalize her bloodline, not Dozie. This latter is treated as such because his father is not of their lineage; only his mother is and she does not count. Her statement confirms Mama Odenigbo's point of view. Male children carry on their family name and protect the lineage from extinction. As a result, a family in which there is no son will extinct. The bloodline or lineage cannot be enlarged. Their girls will help enlarge other people's lineage because their children cannot bear their family name. These are some of the reasons for which both men and women long for male children. But this excessive long for sons is not without consequences for people. It impacts men, women and even the so much cherished and desired male children.

\section{Consequences of Male Child Syndrome and Adichie's Feminist Strategies to CURb THE PHENOMENON}

\subsection{Source of Trauma for Women}

Many people use to say that the role of the novelist is not to propose solutions to social problems but to expose them. I think that Adichie's texts go beyond this statement because she devises solutions to many societal problems after denouncing them.

The first consequence of male child syndrome is that it puts strain on women who get traumatized after failing to give a male child to their husband. Amala is traumatised when she hears that her baby is a girl. It has been clear for her that Mama Odenigbo is looking for a baby boy. That is why she refused to touch her child when she is told it is a girl. This affects her to the point that she refuses to eat and to nurse the baby. All her hope has vanished. It is understandable since Amala has no job and relies solely on Odenigbo for survival. Like Amala, Beatrice is traumatised by her situation. Being the wife of a very wealthy man with only one male child is risky. And that is why Beatrice endures all kinds of harsh treatments from Eugene but is still grateful to him. Women are worried about the sex of the child they will have. Everything happens as if they were the ones who decide what sex their child should be. In this regard, A. Babington-Ashaya (2004) quoted in Ine Nnadi affirmed that women who give birth to female children are often blamed for 'producing girls', by even those who know that a man's chromosomes usually determine the sex of the child. So if there is a person to be blamed for the sex of a baby it must be the man not the woman. But as the Igbo society is highly patriarchal, people accuse women unjustly of being responsible for bearing girls. As Gloria says in her statement above, this belief contributes to Beatrice's trauma after her second miscarriage that's why male child preference is a form of violence against women.

\subsection{Foundation of Polygamy and a Source of High Birth Rate}

Male child preference often leads to polygamy and this can be seen in "On Monday Last week" the fifth story in the collection of short stories TAYN. In the short story, Chinwe, a married woman is crying because her husband is about to pay the bride price to a girl he has just impregnated ${ }^{12}$ (Adichie, 2009, p. 86). The man has done this because Chinwe has two girls while the newly impregnated woman has come from a family of many sons. He is of the view that since the wife-to-be has come from a family of many sons, there is no reason she won't have sons for him. She comes from a lineage or a bloodline in which male genes are numerous. This man's attitude shows his narrow-mindedness and ignorance about how chromosomes determine the sex of a child. The situation shows how women endure mental and psychological anguish because of the will of their husband to have male children at

\footnotetext{
${ }^{10}$ Ibid, p(187)

${ }^{11}$ Chimamanda Ngozi Adichie, The Thing Around Your Neck, p(188)

${ }^{12}$ Chimamanda Ngozi Adichie, The Thing Around Your Neck, 2009 p(86).
} 
all costs. Nothing shows that if Chinwe's husband continue to have children with her, they won't be able to have male children. Also nobody knows whether the new wife will bear a son or not. I notice that because of the quest for male child many men become polygamous.

The 'thirst' for a male child leads many men to become polygamous but in polygamous houses, women compete and every woman uses all legal and illegal means to win the husband over to her side. This sometimes calls for the use of charms in the hearth. By being polygamous men have more children than they can care for. Some of these children and especially the youngest ones are neglected and become delinquent. They add to the thousands who fill our streets with nobody to care for them. So the birth rate increases whereas nothing is done to increase production or wealth. Nigeria is an example in case with more than 170 million inhabitants. This fact creates security problems. Conversely, the so much desired male child, when he comes, is cherished to the extent of being spoilt. Parents make sure he lacks nothing and there is an overt discrimination against the female children. This is what makes Kana fuse(2012) quoted in Ine Nnadi declared that considerable attention has been devoted to this issue of gender preferences for children which is widely observed around the globe as parental gender preferences can cause discriminatory practices against children of the less-desired sex, and these practices can have unfavourable social and demographic consequences. This sometimes leads to siblings' rivalry.

\subsection{Source of Rivalry and Death}

The discrimination or difference of treatment between boys and girls lead some sisters to loathe or hate their blood brothers. This is illustrated by Adichie in TAYN in the following lines:

"The summer you know something had to happen to Nonso so that you could survive. Even at ten you knew that some people can take up too much space by simply being, that by existing, some people can stifle others. The idea of scaring Nonso with the echi eteka was yours alone. But you explained it to Dozie, that you both needed Nonso to get hurt.-may be maim him, may be twist his legs. You wanted to mar the perfection of his lithe body, to make him less lovable to do all that he did. Less able to take up your space"13 (Adichie, 2009, p. 95)

The passage shows how the presence of Nonso in the same environment with her sister prevents her from existing, from being seen. He is given too much care and love by grandmother. Nonso takes for himself all the affection the others might benefit from. When he is with her grandmother, she doesn't mind the others' actions or presence. She is very proud of him and gives him all the love and affection a human being can give another one. There is clear indication that there is a kind of discrimination against the girl just because Nonso is a boy. This arouses hatred and rivalry between Nonso and her sister which ultimately leads to his death. She lets Nonso climb a tree to the top and scares him with echi eteka ${ }^{14}$, the snake whose venom kills within some minutes ${ }^{15}$ (Adichie, 2009, p. 196). He fell from the tree and died. The scene shows the cruelty and sadism of a teenage girl. This wickedness stems from the discrimination she suffers and the affection her brother gets from grandmother. The girl acts out of jealousy. Though the narrator is sure that Nonso's death is a good riddance but even after eighteen years of his death's secret she shares with her cousin Dozie, she feels ruined because Nonso is still the affectionate one of the family. He would not have died had his grandmother not given him more love and affection than others. The end is full of remorse because after the narrator confesses her responsibility in Nonso's death, her cousin Dozie hates her and moves away from her. That is the reason why she is full of guilt and is pained at the very thought of her brother's death but it is already too late.

\subsection{Source of Rejection and Discrimination}

Another consequence that is worth mentioning is that little children from the very onset of their life suffer neglect, undergo rejection and lack motherly love and affection. This is the case of Baby, Amala and Odenigbo's daughter. She is rejected by both her mother and her paternal grandmother. This kind of rejection affects children psychologically and some of them become pitiless when they grow up. Many people think that they do not count. No wonder Beatrice Okoh in The Anthills of

\footnotetext{
${ }^{13}$ Chimamanda Ngozi Adichie, The Thing Around Your Neck, Farafina, 2009, p(195)

${ }^{14}$ A snake in Igboland whose bite kills within minutes

${ }^{15}$ Chimamanda Ngozi Adichie, The Thing Around Your Neck, p(196)
}

International Journal on Studies in English Language and Literature (IJSELL) 
Savannah is called 'Nwanyibuife' which means a woman is also something. Her parents bore a grudge for her from the very beginning of her life. Worst still, some parents refuse to send their children to school because they are female. How can these children contribute to the development of their country in future? How will they be able to fight oppression if they do not have the means to do it?

\section{Adichie's Strategies to Curb the Phenomenon}

"Gender issues are common nowadays and it forms the foundation of the structural inequality pestering almost all the countries." (Menon, 2015, p. 44). To reverse this trend, in PH for instance, Adichie has used irony to give a blow to patriarchy. Towards the end of the novel Purple Hibiscus, Adichie makes the same Papa Nnukwu who says that Aunty Ifeoma does not count because she is a woman, a while later confess: "I joke with you Nwam. Where would I be today if my Chi had not given me a daughter?" Nnukwu recognizes the pivotal role his daughter has played in his life and that women can no longer be relegated to the periphery and ignored as before. Aunty Ifeoma with her limited means accommodates her father and cares for him till his death and gives him a befitting burial. Ifeoma's caring for her father while Eugene is there with all his riches hating him for the sake of religion. This is a clarion call to all boy seekers to stop underestimating women's capacities and capabilities. It is a reversal of situation because the roles she plays are men's.

In HYS, Adichie prominently portrays two women characters whom she uses to deconstruct this patriarchal idea: the long for male children. They are chief Ozobia's twin daughters Olanna and Kainene. Olanna means God's Gold. This is a sharp contrast with Achebe's Nwanyibuife in Things Fall Apart which means that a woman is also something. When Amala has rejected her kid, Olanna has accepted to keep her even though she is not the biological mother and her mother disapproves it. She is even scandalised at hearing that Amala has refused to touch the baby. She (Olanna) has accepted to keep the baby though it is her being betrayed that has led to its conception and birth. Adichie's portrayal of Olanna accepting to keep the baby is a confrontation and a blow to patriarchy. Amala is not educated and is narrow minded that's why she thinks that a baby girl is useless. Olanna who is open- minded knows that both a baby boy and a baby girl have the same rights and should be treated without discrimination of any kind. Olanna has been endowed with the tools to confront patriarchy. She is highly educated and knows very well the importance of educating children especially female ones. She herself is an example in case. Olanna has a car and a flat of her own all that make her not to depend on any man. She is financially and sexually independent. She cannot lie low for anybody. She is not waiting for anybody's heritage or relying on any child for her future. This makes her a woman who can say the truth to anybody, even her own father. Reproaching her father's infidelity, she declares:

\section{It is disrespectful that you have a relationship with this woman and that you have bought her a house where my mother's friends live.... You go there from work and your driver packs outside and you don't seem to care that people see you. It's a slap to my mother's face... I am not going to tell you what to do about it, but you have to do something. My mother isn't happy (Adichie, 2006, p.218).}

In furtherance of the same idea, Adichie has made chief Okonji, the finance minister who was dating Olanna to say this about Kainene: "whoever said you lost out by having twin daughters is a liar",I7 (Adichie, 2003, p. 31) and her father chief Ozobia adds jokingly "Kainene is not just like a son, she is like two" ${ }^{\prime 18}$ (Adichie, 2003,p. 31). Here, Kainene's father is comparing her daughter to two sons. We are accustomed to people longing for male children at all costs but this is a young girl who is worth two sons. Adichie through this text wants to tell the public at large that instead of hating their daughters and neglecting them, they had better educate them correctly and invest money on them to guarantee a prosperous future for them. From chief Ozobia's assertion, we can deduce that "one is not born a woman but becomes a woman" (The Second Sex; 1997: 295) quoted in Butler. Though Kainene was born a daughter, she is transformed into two sons on account of her achievements,

\footnotetext{
${ }^{16}$ Chimamanda Adichie, Purple Hibiscus, Farafina, 2003, P(83)

${ }_{17}^{17}$ Chimamanda Adichie, Purple Hibiscus, Farafina, 2006, p(31)

${ }^{18}$ Ibid
} 
assertion and being empowered. What matters is what parents want to make out of their children. Chief Ozobia is conscious of the fact that he has no boy so he makes boys out of his twin daughters. His attitudes conforms with those who think that "women are an integral part of human civilization and there is no general development of a society or country without an active participation and uplift of women" (Sam et al. 2017, p. 796). If a girl does not internalize all the prejudices and stereotypes about femaleness and femininity in her society, is schooled and highly educated to the extent of knowing her rights, she can challenge boys on any field and can even do better than they can. This is the case of Kainene. She has no inferiority complex whatsoever; she is able to do everything her father can do: make deals, bribes to get contracts and so can rightfully see to it that his businesses thrive.

Adichie through the character of Kainene is urging readers to take good care of their female children and educate them without discrimination of any kind. Through the character of Chief Ozobia, Adichie is saying that contrary to Chinwe's husband who think that salvation must come from boys and become polygamous one can stick to one wife and live a happy and successful life. Chief Ozobia can be compared to Eugene Achike who refused to get a second wife though his people were demanding it. Moreover, our societies are getting more and more industrialised, so people need less and less physical strength. What matters nowadays are intellectual skills and as far as intellectual skills are concerned both boys and girls can have them. That is what makes Adichie declare that:

We live in a vastly different world. The person more likely to lead is not the physically stronger person, it is the more creative person, the more intelligent person, the more innovative person and they are no hormones for those attributes. A man is as likely as a woman to be intelligent, to be creative, to be innovative ${ }^{19}$ (Adechie, 2003, TEDxEuston).

\section{CONCLUSION}

Chimamanda Ngozi Adichie is a literary giant who is known all over the world. She is the leading African writer of her generation. Like her literary forefathers and foremothers, she has noticed the male child preference attitude in Igbo society and discussed it in her texts. This simply means that this problem over the years has not receded but is still relevant. From her first novel PH to the latest one Americanah, there are characters who express their desire for male children. This paper has investigated the reasons why people have such an attitude and the consequences it has on men, women and the children themselves. Throughout my research work I have arrived at the conclusions that women long for male children to guarantee their place in a man's house; both men and women want a male child to carry on their bloodline or lineage because in African societies and especially Nigeria it is men who bear the family name to death. Women change it as soon as they get married and carry their husband's family name. Next, 'only men can inherit their fathers' properties after their death.

This strong desire to have male children have consequences on people. Women after failing to comply with this patriarchal demand suffer traumatisation. Female children are discriminated against and sometimes undergo rejection from the onset of their life. Some women because they have only one son among their children cherished him to the extent of spoiling him. Worse still this provokes a sibling rivalry which can lead to the death of the boy. Last but not least, the long for male children often lead men to become polygamous. Thus they have more children than they can care for and some children are neglected and therefore do not receive the adequate education to contribute to the development of their country. Correspondingly, some Nigerian citizens as epitomised by Aunty Ifeoma in PH, Olanna, Kainene and their father in HYS have demonstrated through their different roles that female children are as worthy as male ones. All children should be treated the same way without discrimination of any kind. Today what a man can do, a woman can do so; there are even women who are worth two sons.

\section{REFERENCES}

[1] Adichie, Chimamanda Ngozi., Purple Hibiscus. New York. Anchor Books

[2] Adichie, Chimamanda Ngozi, 2006, Half of a yellow Sun. New York : Anchor Books

[3] Adichie, Chimamanda Ngozi, The Thing Around Your Neck. New York : Anchor Books, 2009

${ }^{19}$ We should All Be feminists-Chimamanda Ngozi Adichie at TEDxEuston posted on December 30, 2013

International Journal on Studies in English Language and Literature (IJSELL)

Page 29 
[4] Adichie, Chimamanda Ngozi , We Should All Be Feminists, Talk delivered at TEDxEuston London, 2013

[5] Adichie, Chimamanda Ngozi , Americanah, London :Fourth Estate, 2013

[6] Ayisi, E., O. (1980). An Introduction to The Study Of African Culture. London: Heinemann.

[7] Denkyi-Manieson, Gladys, Agyeiwaa. Purple Hibiscus, Half of a Yellow Sun and The Thing Around Your Neck by Chimamanda Ngozi Adichie: A Thematic Study, Africology: The Journal of Pan African Studies, vol.11, no.1, December 2017, pp. 52-65.

[8] El-Gilany, A. H., \& Shady, E. (2007). Determinants and causes of son preference among women delivering in Mansoura, Egypt. Eastern Mediterranean Health Journal, 13(1), 119. Retrieved April 3, 2012, from http://www.emro.who.int/publications/emhj/1301/PDF/15.pdf

[9] Ezeigbo, Theodora Akachi. Traditional Women Institutions in Igbo Society: Implications for the Igbo Female Writer: African languages

[10] Fwangyil, A. Gloria. "A Reformist-Feminist Approach to Chimamanda Ngozi Adichie's Purple Hibiscus ” in African Research Review.5. May 2011 pp (261-274) Web. Oct 2016.

[11] Menon, Ms., K., Gayathri. (2015). Civil War and the Question of Gender Roles in Chimamanda Ngozi Adichie's Half of a Yellow Sun, Literary Quest, VOL. 1 Issue 9 February, ISSN 2349-5650, pp. 43-50.

[12] Ogechukwu A. Ikediugwu. Feminist Inclinations in Chimamanda Ngozi Adichie's Half of a Yellow Sun and Purple Hibiscus, New Academia (Print ISSN 2277-3967) (Online ISSN 2347-2073),Vol. II Issue IV, Oct. 2013, pp.1-16

[13] Purewal, N. K. (2012). Son Preference Sex Selection, Gender and Culture in South Asia. Retrieved from http://www.bergpublishers.com/?TabId=11824

[14] Sam, C., Bibin, Georshia, G., Danish, S., \& Remya, M. (2017). Oppression of Women: Postcolonial Perspectives on Chimamanda Ngozi Adichi's Purple Hibiscus, Research Journal of English Language and Literature (RJELAL), Vol.5.Issue 3. (July-Sept), p796-799

\section{AUTHORS' BIOGRAPHY}

Dr Célestin Gbaguidi is a senior Lecturer of Anglophone African Literature at Abomey-Calavi University in Benin. He holds a Doctorate degree in Anglophone African Literature from the same University. His research interests are mainly gender issues, good governance in the political arena, and youth migration in literature. He is the current Deputy Head of English Department of The University of Abomey Calavi.

Prof. Laure Clémence Zanou Is a senior Lecturer of African Literature and Civilization in the University of Abomey Calavi.

Hubert KPAVODE is Doctoral Student in Anglophone African Studies in the University of Abomey Calavi (Benin Republic). He holds a Post-Graduat Degree (DEA)In the same field. As such, he is a researcher in African. literature and civilization. He also teaches English Language in Benin Secondary Schools.

Citation: Prof. Laure Clémence Capo-Chichi Zanou, et.al. “ The Male Child Syndrome in Chimamanda Ngozi Adichie's Fiction ". International Journal on Studies in English Language and Literature (IJSELL), vol 6, no.11, November2018, pp. 22-30. doi:http://dx.doi.org/10.20431/2347-3134.0611004.

Copyright: (C) 2018 Authors. This is an open-access article distributed under the terms of the Creative Commons Attribution License, which permits unrestricted use, distribution, and reproduction in any medium, provided the original author and source are credited. 